\title{
An Analysis of Women's Dress Changes in the Late Qing Dynasty and the Republic of China
}

\author{
XinYu Hui* \\ Xing Zhi College of Xi'an University of Finance and Economics, Xi'an, Shanxi 710038, China.
}

Abstrct: The period from the late Qing Dynasty to the Republic of China was an era in which China's political, social and cultural changes were radically changed. Therefore, the fashion trend has undergone several changes, and the dress system was even introduced during the Republic of China. Among them, the changes in women's clothing are particularly interesting. With the forced break of the closed state and the success of the new revolution, new changes have appeared in the form and characteristics of women's clothing, which not only reflect the changes in the current situation, but also express China. Unique social and humanistic culture, this article aims to comb and analyze the changes of women's clothing in China during this period, in order to explain the humanistic aesthetic consciousness and modernity reflected in the changes of the times in clothing.

Keywords: Women's Dress Changes; New Revolution on Traditional Clothes; Costume Culture.

The old saying "the world is different incident, the incident time shifting, time shifting the vulgar easy" meant to say that the change in social mores of the times The ethos has also changed. The change of dress is an important manifestation of changing customs. In the late Qing Dynasty and the Republic of China, the current situation was turbulent, the society had undergone several changes, and various cultural factors intertwined and collided. A series of epoch-making changes made Chinese women move from the boudoir to society In the face of the interweaving of tradition and modernity, Chinese and Western, their thinking has undergone tremendous changes, which can also be clearly seen in their clothing.

Before the entry of Manchuria to the establishment of the Republic of China, Manchu costumes were mostly used as the trend. However, with the opening of the country at the end of the Qing Dynasty, people had huge changes in their ideology and concepts in foreign culture, industrial revolution and social innovation, which were reflected in their lives. All aspects of The Chinese began to break through the outdated dressing etiquette and norms, and no longer follow the old rules and regulations. The trend of change in clothing, on the contrary, has a great impact and shock on the late Qing government. Among them, women's clothing has been Freed from the red tape system of the Qing Dynasty, the structure and decoration have become simple and plain, and the basic form is still the upper garment and the lower garment. The following is a classification analysis of the changes ${ }^{[1]}$.

\section{Change of gown}

The robe is a kind of clothes that integrates upper and lower. It is the natural choice of Manchu ancestors in the long-term nomadic fishing and hunting life based on the cold climate in the north. After entering the customs, pheasant hair easy clothing was promoted throughout the country, making it a uniform clothing style throughout the country. With the change of the environment, the change of lifestyle and the great abundance of materials, the early tightly-fitting gowns that are convenient for riding, shooting and hunting have derived more clothing styles, which have become more and more suitable for people's actual life needs. More and more fit and fit. Since ancient times, Chinese women's clothing has basically adopted a straight line style. At the end of the Qing Dynasty, Qimen women's clothing basically kept the old system-loose-fitting cheongsam, silk embroidered waistcoat, two heads, wooden high-soled satin embroidered shoes, the basic shape of the cheongsam was straight, flat sleeves, large flap, right gusset, long and instep, Mainly divided into cloak and shirt, these female gowns are also the embryonic form of "cheongsam" in the modern sense. Among them, from the late Qing Dynasty to the beginning of the Republic of China, the height of the collar has undergone a change from high to low to no collar. Before the Republic of China, cheongsam was not popular among Han women. One is because it is a status symbol. Those who are "in the flag" wear it with caution; secondly, because Han women are not used to wearing high-soled shoes and do not have high headwear, the large cheongsam appears short and awkward behind the body, and there is no flag woman wearing "big wings" and footwear and the "Flowerpot Bottom" graceful style. At the beginning of the 20th century, cheongsam was popularized by women of the Manchu and Han ethnic groups. At this time, the cuffs were narrow and the edges became narrower. In the late 1920s, influenced by foreign culture, the length was significantly shortened, the waist was tightened, the collar was fastened, the curve was sharp, and the rhythm of the slanted placket was added. The clothes were well tailored, and the slits were opened high and under the crotch, down to the knee. So far, a unique improved cheongsam has been

Copyright (C) 2020 XinYu Hui

doi: $10.18282 / 1-e . v 9 i 4.1712$

This is an open-access article distributed under the terms of the Creative Commons Attribution Non-Commercial License (http://creativecommons.org/licenses/by-nc/4.0/), which permits unrestricted non-commercial use, distribution, and reproduction in any medium, provided the original work is properly cited. 
formed. In the heyday of cheongsam in the 1930s, cheongsam styles widely absorbed western styles on the basis of tradition and became a combination of Chinese and Western styles. Since the 1940s, the change of cheongsam has been slow, the body length and sleeve length have been shortened, and the sleeves are not even used in the summer, which is more concise, lighter and more suitable. The modern women's cheongsam is easy to put on and take off, can fully show the beauty of women's body curves, and can be flexibly matched with other types of clothing. It returns to women's daily life with a brand new attitude. Cheongsam with oriental temperament is easy to combine with wearers with corresponding temperament to produce harmonious beauty. "Women's clothes are not expensive and suitable for home, but expensive and suitable for appearance." This feeling produced by clothing and people a harmonious intuitive judgment formed in the aesthetic psychology. It's just that people's class composition and ideological concepts are still very different under the background of the alternation of the new and old ages, but in any case, the style of cheongsam began to revolve around the contour structure of the human body, the texture of the fabric and the novelty of the style.

\section{Jacket skirt}

Women of the Han nationality usually wear tops and skirts or tops and pants. The blouse generally grows below the knee or hip, with a right open placket, a low stand-up collar or a high collar, a round shape, a well-fitted body, and the sleeves are moderately long and narrow. The lower skirt is the most characteristic women's dress since the Qing Dynasty. The color is red, and there are many kinds. In the early period, there were "pleated skirts", "yuehua skirts", "bomb skirts" and so on. Manchu women inherited the customs of the Jurchen tribe like men. They learned to ride horses and archery since they were young, and did not have the habit of wearing skirts. Due to the influence of Han culture after entering the customs, Manchu women also began to wear skirts (mostly tube-shaped), and skirts gradually became a common dress for women in the Qing Dynasty. Regarding the dressing of the top and the bottom of the pants, Zhang Ailing has a vivid description in "The Changing Clothes": "No matter how tight the clothes are, the flesh under the clothes is not a realistic style. It does not look like a woman but a ray of poetry. The straight line of the long coat stretches to the knee, and two narrow trousers hang vainly underneath. The golden lotus, who looks like feet but not feet, gently stepped on the ground apologetically ${ }^{[2]}$."

\section{Gown}

The gown is a common form of outer clothing for women in the late Qing Dynasty and the early Republic of China. There are roughly a variety of styles such as double-breasted, large-breasted, pipa-breasted,herringbone-breasted,straight-breasted, and diagonal-breasted. Many women's gowns in the late Qing Dynasty have the characteristics of the integration of Manchu and Han costumes, as shown $\mathrm{in}^{[3]}$. For example, the female mannequin, its embryonic form comes from the manchu's horse-riding marching suit. After development and evolution, it has become a costume that integrates many costume elements of the Manchu and Han ethnic groups. On the one hand, the Manchu female mandarin jacket was affected by the Han women's clothing, from the initial body length to the crotch, to the length of the dress extending below the hips, and sometimes even to the knees; the originally narrow body and sleeves have gradually become wider; and there is a distinction between wanxiu and shuxiu. On the other hand, what the mangall brings to Han women's gown is a change in the traditional way of binding. The blouses of the Han people in the Ming Dynasty were tied with belts except for one or two gold and silver snaps on the collar. The button loops on the Manchu jackets gave new inspiration to the way of tying Han Chinese Clothing. From the end of Guangxu to Xuantong period, commoner women in Beijing wore a tight-sleeved knee-length shirt similar to a cut cheongsam. They wore long trousers with narrow trousers and bandages around their calves. This kind of attire allows women to move freely and appears concise and concise. Therefore, whether it is a man with a "natural foot" or a Chinese girl with a "three-inch golden lotus", it is worn by all ages. In the space where the new cheongsam alternates with the old cheongsam, this has become the most common type of women's clothing in Beijing.

\section{Waistcoat and hanging}

Waistcoats have been extremely popular since the Qing Dynasty. Waistcoat originally belonged to the clothing of the court officials, but in the subsequent development process it became the general clothing of upper men and women, and later developed in the entire social class. Waistcoats and gowns are sleeveless blouses, as shown ${ }^{[4]}$, which are clothing worn by women in winter, spring, and autumn over cloaks, shirts or cotton robes in the late Qing Dynasty and the early Republic of China. Qimen women are very particular about the styles and colors of waistcoats and gowns, and often wear them on the outside of the gown, and strive to be harmonious, matched and set off with the cheongsam worn inside. Waistcoats and gowns do not cover much of the human body, but because they are worn outside clothes, their fabric selection, decoration techniques and production techniques are more exquisite, often giving people a "small and delicate" feeling. On the contrary, it is not common for Han women to wear waistcoats and gowns. They basically wear more generous gowns, jackets, and shirts ${ }^{[5]}$.

\section{Conclusion}

From the perspective of the entire history of Chinese clothing development, the mainstream clothing of the Chinese nation has developed to modern times, with the characteristics of piled up patterns, various styles, and ingenious craftsmanship. The Qing Dynasty clothing has the most complicated patterns and diverse shapes, which can be called the best clothing in the past. At the same time, this is also an era of great changes in traditional costume forms. The changes in costume culture in the late Qing Dynasty and the Republic of China are unprecedented. It can be described as an important period for eliminating old forms and systems, and gestating and producing new forms. Through the changes in women's clothing in the late Qing Dynasty and the Republic of China, we can see that women have begun to pursue freedom, equality, and individual liberation. In addition, the changes in women's clothing in the late Qing Dynasty and the Republic of China had a certain impact on the diversification of 


\section{Analysis of the Design Methodology Internationalism Characteristic

Zhisheng Xin*

College of Art \& Design, Wuhan Institute of Technology, Hubei 430205, China.

Abstract: The "Grid System" is a methodology used in typography that came into being under internationalism after world war II. This methodology takes control of the image's aspects with the grid lines that equally divides and distributes the space, which resulted in the visual balance and a sense of coordination. As a design method, it represents how mathematical subjects interact with art. And even after decades of evolution, it still acts as a crucial part of art \& design and deeply influenced many designers and their works. This paper starts with the history of the "Gird System" method while introducing its concept and following its major developments and practices, then finishing up with an analysis of its main character and methodology for some future design.

Keywords: Grid System; Graphic Design; Typography; Internationalism Characteristic

The "Grid System" played an important role in unifying and developing the 20-century graphic design. It is commonly used in most designs and has had enormous influences on typography and character design, and other subjects. The rational and balancing ability which carries creates a field of managed and a sense of standardized industrial production. The system isn't a simple form as it seems but a sophisticated measurement of the space and the elements' visual weight. It was an integration of multi-subjects such as psychology, etc. Analysis of the "Grid System" can provide an up-to-date reference of its developments and fundamental principle for our future design practice and offer the possibility to expand the frontiers of design in China and worldwide.

\section{Concept and brief history of Gird System}

\subsection{Concept}

Gird System can essentially be called a kind of framework that controls and regulates the elements on a graphic. The grid represents lines that constructed several rectangles with the same size equally laid on the surface with a balanced pattern. "A netliked mixture made of a pattern of equally distributed crossed horizontal lines and vertical lines" can be the description of the Grid System form. As Anthony Froshaug stated in the article

"Typography is a grid" published in 1976 on designer magazine "grid, n. The frame of spaced parallel bars ... network ... gridiron ...'.Or, 'net, plexus, web, mesh, twill, skein, sleeve, felt, lace; wicker; matting; plait, trellis, wattle, lattice, grating, grille, gridiron, tracery, fretwork, filigree, reticle; tissue, netting[1]", Grid is a means to integrate different sizes of characters and pictures along with other visual aspects to an even and well-distributed whole. But on the practical level, unlike the grid system with its theories and evidence, the grid itself is actually invisible in the final pieces, only acting as a reference during the design, a tool, and a passage for us to orchestrate our work better. Using a grid system, we should use an x-axis and a y-axis as a reference; then, we divided it into two grid forms. One is the point-based grid, which acts on specific coordinates and intersections, while another is a field-based grid that includes module-based and line-based.

\subsection{Brief history of Grid System}

The Gird System is formally established in the early-20s century, but before that, the grid itself has been explored and experimented with for a few centuries. The first known usage of the grid in art \& design was in the early-15s centuries when a new printing method was invented in Gutenberg called "Hot Metal Typesetting". In this initial attempt, the gridded visual aspects

Copyright (C) 2020 Zhisheng Xin

doi: 10.18282/1-e.v9i4.1713

This is an open-access article distributed under the terms of the Creative Commons Attribution Non-Commercial License (http://creativecommons.org/licenses/by-nc/4.0/), which permits unrestricted non-commercial use, distribution, and reproduction in any medium, provided the original work is properly cited.

modern women's clothing aesthetic concepts and clothing systems in China and abroad.

\section{Reference}

[1]Yue Hu, Ze Yuan. A century of clothes The evolution of Chinese clothes in the 20th century[J]. Oriental Art, 2006; (02): 23-33.

[2]Zi'er Cai. History of Chinese Apparel Aesthetics[M]. Hebei Meishu Publishing House,2001.

[3]Heping Zhu. Draft of Chinese Clothing History[M]. Zhongzhou Ancient Books Publishing House, 2001.

[4]Ailing Zhang. Changing clothes[M]. Zhejiang Literature and Art Publishing House, 1981.

[5]Congwen Shen. Research on Ancient Chinese Costumes (Revised Edition)[M]. Shanghai Bookstore Publishing House. 1997. 